\title{
TINJAUAN AGROFORESTRI DAN PENDEKATAN KARAKTER BUDAYA LOKAL DALAM PEMULIHAN LAHAN KRITIS DI KABUPATEN LIMAPULUH KOTA
}

\author{
Desi Widia Kusuma \\ Badan Penelitian dan Pengembangan Provinsi Sumatera Barat \\ JL. Jenderal Sudirman No.51 Padang Sumatera Barat \\ Email : desiranawk@gmail.com
}

\begin{abstract}
Kabupaten Limapuluh Kota memiliki lahan kritis terbesar di Sumatera Barat. Berdasarkan Keputusan Direktur Jenderal Bina Pengelolaan DAS dan Perhutanan, Kementerian Kehutanan Nomor: SK.4/V-DAS/2015 tentang Peta dan Data Hutan dan Lahan Kritis Nasional Tahun 2013, terdapat lahan kritis seluas $94.593,7$ ha dan lahan sangat kritis seluas 32.488 ha di Kabupaten Limapuluh Kota. Angka ini akan terus bertambah jika tidak dilakukan upaya pemulihan yang tepat. Dengan topografi didominasi berbukit dan kelerengan besar dari $40 \%$, Program Agroforestry sangat cocok dikembangkan untuk mengatasi lahan kritis di Kabupaten Limapuluh Kota. Upaya pemulihan lahan kritis di Kabupaten Limapuluh Kota harus dilakukan secara terpadu antara teknologi dan karakter budaya lokal. Kajian ini bertujuan untuk memperoleh informasi tentang pemulihan lahan kritis dengan sistem agroforestri dan karakteristik Masyarakat Minangkabau sebagai karakter budaya lokal. Metode yang digunakan adalah deskriptif kualitatif dengan teknik wawancara dan penelusuran dokumen. Hasil kajian menunjukkan bahwa karakter budaya Masyarakat Minangkabau harus menjadi perhatian/pertimbangan dalam pengembangan Program Agroforestry sebagai dasar pelibatan partisipasi masyarakat di Kabupaten Limapuluh Kota agar dapat berhasil. Beberapa karakter yang dianut oleh Masyarakat Minangkabau dalam pengambilan keputusan adalah : otoritas, musyawarah/mufakat, kepemimpinan, sikap kritis terhadap perubahan, egalitarian dan demokrasi serta tanah ulayat. Karakter tersebut dapat dijadikan pertimbangan dalam menerapkan program agroforestri di Kabupaten Limapuluh Kota.
\end{abstract}

Kata Kunci : lahan kritis, agroforestri, karakter budaya lokal, Masyarakat Minangkabau.

\section{AGROFORESTRY AND CHARACTER OF LOCAL CULTURE APPROACH REVIEW AT CRITICAL LAND REHABILITATION IN LIMAPULUH KOTA REGENCY}

\begin{abstract}
Limapuluh Kota Regency has the largest critical land in West Sumatra. Based on the Decree of the Director General of Management of Watershed and Forestry, Ministry of Forestry Number: SK.4 / V-DAS / 2015 on National Forest Critical Map and Data of 2013, there is a critical land area of 94,593.7 ha and very critical land area of 32,488 ha In Limapuluh Kota Regency. This number will continue to grow if no appropriate recovery is done. With hilly dominated topography and large slopes of $40 \%$, the Agroforestry Program is well suited to be developed to address critical lands in Limapuluh Kota Regency. The effort to restore critical land in Limapuluh Kota Regency must be integrated in between technology and character of local culture. This study aims to obtain information on the recovery of critical land with agroforestry systems and the characteristics of the Minangkabau Community. The method used is qualitative descriptive with interview technique and document tracking. The results of the study indicate that the cultural character of the Minangkabau Community should be a concern / consideration in the development of the Agroforestry Program as the basis for the involvement of community participation in Limapuluh Kota Regency in order to
\end{abstract}


succeed. Some of the characters adopted by the Minangkabau community in decision-making are: authority, deliberation/consensus, leadership, critical attitude toward change, egalitarian and democracy and ulayat lands. The character can be considered in applying agroforestry program in Limapuluh Kota Regency.

Key words : critical land, agroforestry, character of local culture, Minangkabau Society.

(C) 2017 Desi Widia Kusuma

\section{PENDAHULUAN}

Isu perubahan iklim merupakan salah satu isu yang paling krusial dewasa ini. Beberapa dampak negatif yang sudah dirasakan akibat terjadinya perubahan iklim antara lain : cuaca ekstrim, perubahan musim hujan, kekeringan, banjir bandang, berkembangnya beberapa wabah penyakit dan sebagainya Dampak tersebut tidak hanya lintas daerah, bahkan sudah menembus lintas negara. Begitu pentingnya isu sehingga dunia internasional pun turun tangan untuk dapat mengatasinya. Pertemuan terakhir yang diselenggarakan oleh dunia internasional (dalam Konferensi Tingkat Tinggi/KTT) dalam membahas perubahan iklim telah dilaksanakan di Paris pada 30 November - 12 Desember 2015 yang dikenal dengan Paris Agreement yang sebelumnya dilaksanakan di Bali 3-14 Desember 2007. Point penting dari konfrensi tersebut adalah membatasi pemanasan global melalui penguragang emisi gas rumah kaca hingga maksimum 2 derajat celcius hingga tahun 2100. Indonesia sebagai salah satu negara peserta KTT, telah berkomitmen untuk mengurangi emisi gas rumah kacanya sebesar $29 \%$ sampai tahun 2030 dengan upaya sendiri dan $41 \%$ dengan bantuan dunia internasional.

Sektor yang meyumbang terjadinya emisi gas rumah kaca antara lain : hutan dan lahan, limbah, energi dan transportasi. Sektor lahan dan hutan di Indonesia saat ini ditengarai merupakan penyumbang emisi gas rumah kaca terbesar sebagaimana hasil penelitian Guido van der Werf dari Global Fire Emissions Database yang menyatakan bahwa emisi karbon akibat kebakaran hutan dan lahan di Indonesia telah mengalahkan rata-rata emisi karbon harian
Amerika Serikat. Menurut data tersebut hanya dalam 26 hari saja emisi karbon yang dihasilkan mencapai 1.043 juta metrik ton.

Selain akibat kebakaran lahan dan hutan, emisi gas rumah kaca dapat berasal dari degradasi dan deforestasi lahan dan hutan seperti gambut, illegal logging dan lahan kritis. Besarnya lahan kritis di Indonesia, harus menjadi perhatian dari semua pihak baik pemeritah, dunia usaha dan masyarakat. Sampai tahun 2016 ini, diperkirakan luas lahan kritis di Indonesia mencapai 24,3 juta hektar. Salah satu provinsi yang juga memiliki lahan krits adalah Provinsi Sumatera Barat dimana kontribusi lahan kritis terbesar berasal dari Kabupaten Limapuluh Kota.

Besarnya potensi sumberdaya alam di daerah ini memang menjadi potensi ekonomi yang dapat dikembangkan di berbagai sektor, terutama dari sektor perkebunan/pertanian yang dominan serta pertambangan, namun di sisi lain kondisi ini memberikan tekanan pada lingkungan yang mengakibatkan penurunan kualitas lingkungan. Hal ini dapat ditandai dengan meningkatnya jumlah lahan kritis di Kabupaten Limapuluh Kota (SLHD Kabupaten Limapuluh Kota, 2015). Berdasarkan Keputusan Direktur Jenderal Bina Pengelolaan DAS dan Perhutanan, Kementerian Kehutanan Nomor : SK.4/V-DAS/2015 tentang Peta dan Data Hutan dan Lahan Kritis Nasional Tahun 2013, terdapat lahan kritis seluas $94.593,7$ ha dan lahan sangat kritis seluas 32.488 ha di Kabupaten Limapuluh Kota.

Terkait dengan lahan kritis ini, dalam Buku Status Lingkungan Hidup Daerah (SLHD) Sumatera Barat Tahun 2011, dinyatakan bahwa Kabupaten Limapuluh Kota sering mengalami bencana alam (banjir, 
kekeringan, longsor dan kebakaran hutan) dan sekaligus memiliki status kerusakan lahan dan hutannya akibat lahan kritisnya yang cukup luas dibanding kabupaten/kota lainnya. Bencana banjir dan longsor yang hampir terjadi setiap tahun terjadi terutama pada waktu memasuki musim hujan. Curah hujan yang tinggi dan luasnya lahan kritis menyebabkan tanah tidak mampu menahan beban air sehingga terjadi longsor. Sementara kondisi Daerah Aliran Sungai (DAS) yang sudah mengalami kerusakan memicu terjadinya banjir karena perbedaan debit maksimum dan minimum yang yang cukup besar (SLHD Kabupaten Limapuluh Kota, 2015).

Terjadinya lahan kritis tidak terlepas dari praktek alih fungsi lahan yang menyebabkan kerusakan hutan dan Daerah Aliran Sungai (DAS) di Kabupaten Limapuluh Kota. Isril Berd, 2002 dan Dinas Kehutanan Provinsi Sumatera Barat, 2002 menyatakan bahwa hutan lindung yang luasnya 74.906 ha, telah berubah fungsi tata guna lahannya seluas 54.202 ha untuk perkebunan, belukar dan alang-alang.

Jumlah lahan kritis ini akan terus meningkat jika tidak dilakukan upaya penanganan/pemulihan yang tepat. Salah satu solusi pemulihan lahan kritis adalah dengan Sistem Agroforestri. Penelitian terkait agroforestri dan pelibatan partisipasi masyarakat sudah banyak dilakukan diantaranya Gerson Njurumana, 2007 yang melakukan penelitian di Sumba, NTT menyatakan bahwa apresiasi terhadap berbagai inisiatif lokal menjadi bagian integral dari strategi rehabilitasi melalui penguatan dan pemberdayaan terhadap model agrosylvopasture. Namun kajian/penelitian agroforestri dan menggunakan pendekatan karakter budaya masyarakat untuk pemulihan lahan kritis belum banyak dilakukan terutama di Kabupaten Limapuluh Kota. Yang menjadi permasalahan adalah bagaimana agroforestri dan pendekatan karakter budaya masyarakat Minangkabau dapat diberdayakan dalam pemulihan lahan kritis di Kabupaten Limapuluh Kota agar tepat sasaran. Adapun tujuan kajian ini adalah untuk mengetahui informasi awal tentang sistem agroforestri dan pendekatan karakter budaya masyarakat Minangkabau sebagai solusi untuk pemulihan lahan kritis di Kabupaten Limapuluh Kota.

\section{BAHAN DAN METODA}

Kajian bersifat deskriptif kualitatif dengan waktu pengumpulan data mulai Bulan Mei - Juli 2017 dengan lokasi di Kabupaten Limapuluh Kota, focus lokasi di Kecamatan Pangkalan Koto Baru. Adapun tekhnik pengumpulan data yang dilakukan adalah pengumpulan data sekunder berupa dokumen teknis dan data instansi terkait, wawancara dengan beberapa instansi di Kabupaten Limapuluh Kota : Dinas Lingkungan Hidup, Pemukiman dan Perumahan; Dinas Pertanian Tanaman Pangan dan Holtikultura, Wali Nagari Pangkalan serta Dinas Kehutanan Provinsi Sumatera Barat. Data yang diperoleh dianalisis dengan melakukan identifikasi, klasifikasi, eksplanasi dan penarikan kesimpulan.

\section{HASIL DAN PEMBAHASAN Gambaran Umum Wilayah Kabupaten Limapuluh Kota}

Kabupaten Limapuluh Kota terletak antara 025 '28,71''LU dan 0 22'14,52'LS. Pada Tahun 2015, Kabupaten ini memiliki jumlah penduduk sebanyak 352.949 jiwa. Luas daratan mencapai $3.354,30 \quad \mathrm{Km}^{2}$. Kabupaten Limapuluh Kota memiliki 13 Kecamatan, yang terluas adalah Kecamatan Kapur IX dan terkecil adalah Kecamatan Luak yakni 61,68 $\mathrm{Km}^{2}$. Didaerah ini juga terdapat 3 (tiga) gunung berapi yang tidak aktif serta 17 buah sungai besar dan kecil, 7 embung dan 1 waduk. Disamping itu kondisi wilayah Kabupaten Limapuluh Kota masih didominasi oleh kawasan hutan. Sebagian besar merupakan kawasan hutan lindung yakni seluas 121.102 ha, Hutan Produksi Terbatas, Hutan Konservasi seluas $11.376 \mathrm{Ha}$ dan $2.85 \mathrm{Ha}$ merupakan Hutan Produksi Tetap (Limapuluh Kota dalam Angka, 2015) 
Topografi Kabupaten Limapuluh Kota

Topografi Kabupaten Limapuluh Kota bervariasi antara datar, bergelombang dan berbukit-bukit dengan ketinggian dari permukaan laut antara $110 \mathrm{~m}$ dan $2.261 \mathrm{~m}$. Keadaan topografi ini dapat dilihat dari kelas lereng Kabupaten Limapuluh Kota sebagaimana Tabel 1 berikut :

Tabel 1. Klasifikasi Lereng dan Luas Menurut Kecamatan

\begin{tabular}{|c|c|c|c|c|c|c|}
\hline \multirow{2}{*}{ No } & \multirow{2}{*}{ Kecamatan } & \multicolumn{4}{|c|}{ Klasifikasi Lereng dan Luas (Ha) } & \multirow{2}{*}{ Jumlah } \\
\hline & & $0-2 \%$ & $2-5 \%$ & $15-40 \%$ & $\geq 40 \%$ & \\
\hline 1. & Payakumbuh & $3,121.45$ & $2,846.75$ & $2,287.81$ & $1,690.99$ & $9,947.00$ \\
\hline 2. & Akabiluru & $1,508.16$ & $2,262.24$ & $2,356.50$ & $3,299.10$ & $9,426.00$ \\
\hline 3. & Luak & $1,048.56$ & $1,418.64$ & $1,542.00$ & $2,158.80$ & $6,168.00$ \\
\hline 4. & Lurah Sago Halaban & $6,317.60$ & $9,476.40$ & $9,871.25$ & $13,819.75$ & $39,485.00$ \\
\hline 5. & Situjuah Limo Nagari & $1,186.88$ & $1,780.32$ & $1,854.50$ & $2,596.30$ & $7,418.00$ \\
\hline 6. & Harau & $7,085.60$ & $9,586.40$ & $10,420.00$ & $14,588.00$ & $41,680.00$ \\
\hline 7. & Guguak & $2,442.60$ & $1,805.40$ & $2,655.00$ & $3,717.00$ & $10,620.00$ \\
\hline 8. & Mungka & $1,423.92$ & $1,926.48$ & $2,094.00$ & $2,931.60$ & $8,376.00$ \\
\hline 9. & Suliki & $2,327.98$ & $3,149.62$ & $3,423.50$ & $4,792.90$ & $13,694.00$ \\
\hline 10. & Bukik Barisan & $5,001.40$ & $6,766.60$ & $7,355.00$ & $10,297.00$ & $29,420.00$ \\
\hline 11. & Gunuang Omeh & $2,661.18$ & $3,600.42$ & $3,913.50$ & $5,478.90$ & $15,654.00$ \\
\hline 12. & Kapur IX & $11,573.76$ & $17,360.64$ & 18.084 .00 & $25,317.60$ & $54,252.00$ \\
\hline 13. & Pangkalan Koto Baru & $11,392.96$ & $17,089.44$ & $17,801.50$ & $24,922.10$ & $71,206.00$ \\
\hline & Jumah & $57,092.05$ & $79,069.35$ & $65,574.56$ & $115,610.04$ & $317,346.00$ \\
\hline
\end{tabular}

Sumber : Lima Puluh Kota Dalam Angka, 2015

Dari Tabel 1 tersebut terlihat bahwa kelas lereng $\geq 40 \%$ mendominasi wilayah di Kabupaten Limapuluh Kota yakni seluas 115.610,04 ha. Hal ini mengindikasikan bahwa Kabupaten Limapuluh Kota memiliki topografi berbukit terutama di Pangkalan Koto Baru, Kapur IX dan Harau.

\section{Identifikasi Lahan Kritis dan Faktor Penyebabnya}

Besaran/luasan lahan kritis, terdapat beberapa perbedaan data dari beberapa sumber. Hal ini kemungkinan disebabkan oleh perbedaan metode (bahan dan alat) dalam melakukan pengukuran lahan kritis. Beberapa sumber yang dijadikan rujukan untuk mengidentifikasi lahan kritis dakam kajian ini antara lain : Dinas Kehutanan Provinsi Sumatera Barat, BP DAS Kampar dan Status
Lingkungan Hidup Daerah (SLHD) Kabupaten Limapuluh Kota. Lahan kritis beserta luasannya di Kabupaten Limapuluh Kota berdasarkan SLHD Kabupaten Limapuluh Kota Tahun 2015 dapat dilihat pada Tabel 2. Dari Tabel 2 terlihat bahwa, lahan kritis terbesar terdapat di Kecamatan Pangkalan Koto Baru yakni seluas 29.807 ha, disusul Kecamatan Kapur IX seluas 28.312 ha dan Kecamatan Harau seluas 12.801,10 ha. Berdasarkan Keputusan Direktur Jenderal Bina Pengelolaan DAS dan Perhutanan, Kementerian Kehutanan Nomor : SK.4/VDAS/2015 tentang Peta dan Data Hutan dan Lahan Kritis Nasional Tahun 2013, terdapat lahan kritis seluas 94.593,7 ha dan lahan sangat kritis seluas 32.488 ha di Kabupaten Limapuluh Kota. 
Tabel 2.Daerah lahan kritis beserta luasannya di Kabupaten Limapuluh Kota

\begin{tabular}{clrc}
\hline No. & \multicolumn{1}{c}{ Kecamatan } & Kritis (Ha) & Sangat Kritis (Ha) \\
\hline 1. & Payakumbuh & $2.778,20$ & 32,40 \\
2. & Akabiluru & $1.882,90$ & 819,20 \\
3. & Luak & $4.201,20$ & 638,80 \\
4. & Lareh Sago Halaban & $7.409,80$ & 391,50 \\
5. & Situjuah Limo Nagari & 943,60 & $1.461,10$ \\
6. & Harau & $12.801,10$ & 343,40 \\
7. & Guguak & $5.897,10$ & - \\
8. & Mungka & $9.365,90$ & 167,50 \\
9. & Suliki & $5.416,30$ & - \\
10. & Bukik Barisan & $12.638,50$ & 101,00 \\
11. & Gunuang Omeh & $9.236,50$ & 466,00 \\
12. & Kapur IX & $28.312,00$ & $1.765,00$ \\
13. & Pangkalan Koto Baru & $29.807,00$ & 291,00 \\
& Total & & $134.637,46$ \\
\hline
\end{tabular}

Sumber : Buku SLHD Kabupaten Limapuluh Kota, 2015

Disamping itu, dalam Rencana Aksi Pengendalian Pencemaran DAS Kampar, 2016 dinyatakan bahwa saat ini lahan kritis pada wilayah DAS Kampar Kanan Hulu seluas 75.736 ha yang terbagi dalam tiga kecamatan di Kabupaten Lima Puluh Kota yaitu Kecamatan Bukit Barisan, Kapur IX dan Kecamatan Pangkalan Koto Baru.

Faktor penyebab terjadinya lahan kritis di Kabupaten Limapuluh Kota tidak terlepas dari potensi sumberdaya alam (SDA) yang ada. Dengan potensi tersebut, dapat memberi peluang terhadap eksploitasi SDA. Besarnya potensi SDA terutama di sektor perkebunan dan pertambangan yang dimiliki oleh daerah ini dapat dilihat dari RTRW Kabupaten Limapuluh Kota, dengan deskripsi sebagai berikut :

- Kawasan hutan lindung sebagian besar terletak di bagian Utara Kabupaten Lima Puluh Kota yang berbatasan dengan Provinsi Riau dan sebagian kecil berada di bagian Selatan Kabupaten Lima Puluh Kota, membentang dari Barat Laut ke Tenggara. Kawasan hutan lindung di bagian Utara Kabupaten Limapuluh Kota terdapat di Kecamatan Kapur IX, Kecamatan Pangkalan Koto Baru, Kecamatan Guguak, dan Kecamatan Bukit Barisan. Sedangkan di bagian Selatan
Kabupaten Lima Puluh Kota meliputi bagian Utara Kecamatan Harau, bagian Utara Kecamatan Payakumbuh, bagian Selatan Kecamatan Gunung Omeh, bagian Selatan Kecamatan Lareh Sago Halaban, dan bagian Barat Kecamatan Akabiluru.

- Wilayah Pengembangan II (WP Utara); meliputi kecamatan-kecamatan: Kapur IX dan Pangkalan Koto Baru. Adapun produk unggulannya adalah jeruk, manggis, padi ladang, kacang panjang, ketimun, karet, dan gambir

- Kawasan hutan yang dapat dikonversi sebagian besar berada di bagian Utara Kabupaten Lima Puluh Kota, yaitu di bagian Utara Kecamatan Kapur IX dan di bagian Timur Kecamatan Pangkalan Kota Baru

- Hasil bahan galian vital terdiri dari emas, batubara, dan timah hitam. Emas terdapat di Nagari Manggani (Kecamatan Gunung Omeh). Batubara terdapat di Desa Gelugur (Kecamatan Kapur IX), dan Nagari Pilubang dan Ketinggian (Kecamatan Harau). Timah hitam terdapat di Nagari Tanjung Balit (Kecamatan Pangkalan Koto Baru).

- Bahan galian $\mathrm{C}$ yang mendominasi adalah batu cincin, tanah liat. Batu cincin terdapat di Nagari Sungai Rimbang (Kecamatan Suliki). Tanah liat terdapat di Kec. Harau 
(Nagari Ketinggian, Nagari Limbuku, Nagari Batubalang, dan Nagari Sarilamak), Kecamatan Payakumbuh (Nagari Sungai beringin, dan Taeh Bukit), (Kecamatan Akabiluru Nagari Piladang, Batu ampang), Kecamatan Guguak (Nagari Dangungdangung), dan Kecamatan Lareh Sago Halaban (Tanjung Gadang).

Dari hasil wawancara dengan Dinas Pertanian, Tanaman Pangan dan Holtikultura diperoleh informasi bahwa salah satu penggunaan lahan yang cukup besar di Kabupaten Limapuluh Kota adalah untuk kegiatan perkebunan. Beberapa komoditi perkebunan antara lain: Karet, Kelapa, Tembakau, Kopi Robusta, Kopi Arabika, Gambir, Enau/Aren, Kakao dan Pinang. Komoditi perkebunan yang paling banyak adalah gambir dan lokasi terluas adalah di Kecamatan Pangkalan yakni seluas 2.490,29 Ha dan di Kecamatan Kapur IX seluas 3.725 Ha. Gambir banyak diusahakan oleh perorangan di daerah lereng bukit.

Permasalahan yang timbul akibat perkebunan gambir ini adalah kegiatan penanaman yang tidak memperhatikan kaidahkaidah konservasi tanah dan air. Gambir yang ditanam di lereng bukit, seharusnya menggunakan teknik terasering, namun karena membuat terasering memerlukan biaya yang agak besar sehingga perkebunan gambir tidak menggunakan terasering. Gambir yang diusahakan masyarakat tergantung harga pasar, jika harga pasar sedang tinggi (pada tahun lalu sempat mencapai Rp. 120.000/kg) maka masyarakat juga sangat banyak yang berladang gambir. Sampai saat ini, Dinas Pertanian terkendala melakukan sosialisasi terkait dengan pertanian ramah lingkungan karena pemilik gambir pada umumnya perorangan, hanya sedikit yang membentuk Kelompok Tani.

Kondisi ini sejalan dengan data dari Rencana Aksi Pengendalian Pencemaran DAS Kampar, sektor perkebunan di Kabupaten Lima Puluh Kota pada wilayah yang termasuk DAS Kampar Hulu adalah gambir (Kecamatan Bukit Barisan), gambir, karet, pinang, kelapa dan kakao (Kecamatan Kapur IX), gambir, karet, pinang, kelapa, kopi robusta dan coklat
(Kecamatan Pangkalan Koto Baru)

Perkebunan karet dan gambir juga merupakan tanaman yang dikembangkan masyarakat di kawasan perbukitan, bahkan gambir banyak ditanam pada lahan dengan kemiringan yang relatif tinggi. Secara khusus, perkebunan gambir banyak dilakukan di perbukitan berlereng relatif tajam yaitu pada kawasan hutan perbukitan yang tidak bernilai. Sementara, perkebunan kelapa sawit banyak dilakukan di daerah dataran rendah, seperti di Kecamatan Kapur IX dan Pangkalan Koto Baru. Selain perkebunan gambir yang dimiliki masyarakat, juga terdapat perkebunan sawit yang dikelola oleh PTPN VI dengan luas lahan 1300 ha yang merupakan alih fungsi tanaman dari perkebunan karet kepada perkebunan sawit, dimulai sejak tahun 2011.

Praktek budidaya pertanian seperti ladang gambir dan perladangan berpindah pada lahan miring dan curam bahkan sampai merambah ke hutan lindung telah menyebabkan kerusakan ekosistem sehingga sistem penyangga kehidupan terganggu dan berdampak pada keseimbangan neraca air, dan berdampak pula terhadap defisit air selama dekade terakhir ini dan telah mengganggu keberlanjutan fungsi dan peran waduk Koto Panjang ( $R A P$ DAS Kampar, 2016). Disamping itu, pada saat pembukaan lahan, dilakukan dengan cara membakar sehingga lahan menjadi rusak dan kritis.

\section{Pemulihan Lahan Kritis dengan Sistem Agroforestri}

Lahan kritis adalah lahan yang keadaan fisik, kimia dan biologi tanahnya tidak atau kurang produktif. Hal ini dikarenakan tanah telah kehilangan lapisan tanah bagian atas (top soil) yang subur karena pengaruh erosi. Selanjutnya Rukmana, 1995 dalam Rahmaddin, 2013 menyatakan bahwa penyebab lahan kritis antara lain :

1. Perladangan berpindah disertai penebangan dan pembakaran hutan.

2. Praktek sistem pertanian yang tidak memperhatikan konsep pengawetan tanah.

3. Penggembalaan liar dan kebakaran hutan. 
Bujang Rusman, 2017 menyampaikan bahwa Agroforestri merupakan salah satu cara untuk merehabilitasi lahan kritis, dengan kemiringan $>30 \%$ dan tanahnya peka erosi. Data dari Balai Pengelolaan (BP) DAS Kampar, Kabupaten Limapuluh Kota memiliki tingkat bahaya erosi (TBE) cukup tinggi diimana 31,55 \% Tingkat Erosi Berat dan $60,52 \%$ Tingkat Erosi Sangat Berat. Dengan ini kondisi tanah yang peka erosi dan didominasi kelerengan $>40 \%$ maka Agroforestri sangat cocok dikembangkan di daerah ini. Lebih lanjut Vergara (1982) dalam Helen Tiorita (2012) menyatakan bahwa agroforestry merupakan salah satu pola atau suatu sistem tata guna lahan yang lestari dan terpadu yaitu antara komponen tanaman budidaya (pertanian) dan tanaman pohon/kehutanan dengan atau tanpa komponen piaraan/peternakan atau perikanan ikan dan udang. Dengan demikian diharapkan produktivitas lahan menjadi optimal dan berkesinambungan. Faktor manusia setempat (sosial, ekonomi dan budaya) perlu dijadikan pertimbangan, di samping faktor ekologi setempat (vegetasi, tanah, iklim, dan sebagainya).

Lebih lanjut Kurniatun Hariah, $d k k$, 2003 memaparkan jenis-jenis agroforestri yang merupakan bentuk kombinasi dari 3 (tiga) komponen agroforestri yani : kehutanan, pertanian dan peternakan, yakni :

1. Agrisilvikultur yakni kombinasi antara komponen atau kegiatan kehutanan (pepohonan, perdu, palem, bambu, dll.) dengan komponen pertanian.

2. Silvopastura yakni kombinasi antara komponen atau kegiatan kehutanan dengan peternakan

3. Agrosilvopastura yakni kombinasi antara komponen atau kegiatan pertanian dengan kehutanan dan peternakan/hewan

\section{Pendekatan Karakter Budaya Masyarakat Minangkabau dalam pelaksanaan Agroforestri}

Adanya pertimbangan sosial, ekonomi dan budaya dalam agroforestri dapat dilaksanakan melalui pendekatan lokal. Nurul
Ikhsan, 2015 menyatakan bahwa pendekatan lokal tidak hanya terkait dengan konteks pemerintahan lokal, tetapi juga memanfaatkan kearifan lokal masyarakat. Kearifan lokal ini bersumber dari nilai-nilai agama maupun budaya yang melekat pada keseharian masyarakat. Nilai-nilai yang sudah melekat dalam kehidupan masyarakat ini akan memudahkan karena masyarakat tidak membutuhkan penafsiran yang rumit atas apa yang harus dilakukan. Modal sosial masyarakat ini akan lebih berefek jika kemudian dipadukan dengan kelembagaan, teknologi dan pendanaan.

Arah kebijakan dalam pengelolaan hutan dan kehutanan saat ini adalah rehabilitasi lahan terdegradasi dan konservasi sumber daya hayati dengan mengikutsertakan masyarakat secara aktif dalam setiap kegiatannya. Hal ini dikarenakan laju peningkatan lahan kritis cukup tingg (Gerson ND. Njurumana, dkk, 2008).

Terkait dengan pelibatan partisipasi masyarakat, Diana Conyers (1991) dalam Aris Tri Cahyo Purnomo (2015) menyatakan bahwa partisipasi masyarakat mempunyai sifat sangat penting, yakni :

1) Partisipasi masyarakat merupakan suatu alat guna memperoleh informasi mengenai kondisi, kebutuhan, dan sikap masyarakat setempat, tanpa kehadirannya program pembangunan serta proyek-proyek akan gagal.

2) Masyarakat akan mempercayai proyek maupun program pembangunan jika ikut dilibatkan dalam proses persiapan dan perencanaan, karena mereka lebih mengetahui tentang proyek atau program tersebut sehingga mereka merasa memiliki terhadap program atau proyek tersebut.

3) Adanya partisipasi umum, karena timbul anggapan bahwa merupakan suatu hak demokrasi bila masyarakat dilibatkan dalam pembangunan masyarakat mereka sendiri, mereka mempunyai hak untuk turut 'urung rembug'

Partisipasi masyarakat seyogyanya menjadi perhatian dalam setiap pelaksanaan suatu program/kegiatan/kebijakan yang akan 
diluncurkan oleh pemerintah. Masyarakat jangan hanya dijadikan objek yang dianggap perlu mendapat bantuan tapi juga sekaligus sebagai subjek yang akan melaksanakan program dimaksud. Oleh sebab itu sebelum meluncurkan suatu kebijakan/program/kegiatan, maka sebaiknya dilakukan terlebih dahulu pemetaan sosial terhadap masyarakat terkait usulan-usulan, persepsi, keinginan, tingkat pemahaman/pengetahuan, rantai pemasaran suatu produk dan lain sebagainya. Sebagai contoh adalah penelitian yang dilakukan Indriana Puspita Widyasari (2008) terkait pilot project IPAL untuk limbah industri tahu yang berada di bantaran Sungai Bajak di Kelurahan Jomblang Kota Semarang, dimana pembangunan IPAL tersebut tidak memberikan perubahan yang berarti pada kondisi sungai. Hal ini disebabkan karena masyarakat kurang diberikan pemahaman yang cukup tentang manfaat pengelolaan limbah sehingga kurang terlibat dan kurang bertanggung jawab terhadap program dan keberhasilannya.

Sejalan dengan hal tersebut di atas (Alvon Kurnia Palma, 2015) memberikan gambaran bahwa partisipasi masyarakat akan menciptakan kekuatan yang mengikat dari suatu aturan karena masyarakat ada rasa kepemilikan (sense of belonging) dan tanggung jawab moral untuk melaksanakan apa yang telah dirumuskan bersama sehingga diperoleh 2 (dua) keuntungan :

1). Pekerjaaan pemerintah menjadi terbantu, sehingga pemerintah dapat melakukan pekerjaan yang lebih penting 2) Bermitra dengan masyarakat akan menghemat alokasi dana tertentu sehingga bisa diarahkan untuk keperluan lain yang sifatnya meningkakan pelayanan publik.

Budaya masyarakat di Kabupaten Limapuluh Kota tidak terlepas dari budaya masyarakat Sumatera Barat. Mayoritas masyarakat Sumatera Barat adalah etnik Minangkabau dan muslim (Hasanuddin, 2013). Komunitas masyarakat adat Minangkabau memiliki ciri khas, keunikan budaya dan spesifikasi tersendiri yang berbeda bila dibandingkan dengan suku bangsa atau masyarakat adat lainnya. Salah satu ciri khas budaya masyarakat adat Minangkabau adalah tatanan kehidupan yang dibangun atas dasar komunalisme, egaliter dan memiliki sistem aturan dan konsep pemerintahan demokratis serta struktur masyarakatnya yang terbentuk berdasarkan kesamaan geneologis dan teritorial (Alvon Kurni Palma, 2005).

Hasanuddin (2013) menyatakan bahwa latar belakang sosio kultural masyarakat Minangkabau adalah matrilineal dan penganut kepercayaan yang kuat kepada Islam. Sekalipun telah mengalami pergeseran, karakter sosio kultural yang bercirikan komunalistik, egalitarian dan demokratis, namun masih membekas dan memiliki peranan yang penting dalam berbagai proses sosial, termasuk dalam menentukan dukungan bagi suatu kebijakan pemerintah dan atau pembangunan. Disamping itu, faktor etik cultural juga berengaruh terhadap dukungan atau penolakan terhadap suatu kebijakan pemerintah walaupun kebijakan itu ada dalam kerangka pembangunan. Faktor moral tersebut didasari oleh ajaran adat dan ajaran Islam.

Lebih lanjut Hasanuddin, (2013) yang sejalan dengan Saleh (1996) menyatakan bahwa terdapat 6 (enam) faktor yang harus dipertimbangkan dalam pendekatan pembangunan di Sumatera Barat. Keenam faktor tersebut merupakan hal yang potensial sebagai pendorong atau sebaliknya sebagai penghambat bagi pembangunan di Sumatera Barat, terutama di pedesaan. Faktor-faktor tersebut adalah :

1. Institusi-institusi sosial tradisional Minangkabau

Institusi-institusi sosial tradisional Minangkabau ini masih dihargai dan memiliki otoritas/kekuasaan, yakni : (a) sistem extended family (keluarga besar), (b) masjid dan surau, (c) pemimpin agama dan pemimpin adat, dan (d) kaum cerdik pandai/ cendikiawan.

2. Dalam proses dan mekanisme pengambilan keputusan, masih menjunjung tinggi prinsip musyawarah dan mufakat

- Semua unsur harus terlibat, pada posisi duduk sama rendah tegak sama tinggi. 
- Untuk menghasilkan sebuah keputusan yang berkualitas, maka perbedaan pendapat tidak saja diakui dan diterima, melainkan menjadi suatu keharusan (bersilang kayu dalam tungku, dengan begitu maka api akan hidup)

- Proses demikian memang memakan waktu yang relatif panjang, namun pengabaian mekanisme tersebut akan berdampak pada kurangnya partisipasi warga dalam mendukung pelaksanaan keputusan yang dihasilkan. Partisipasi masyarakat harus digalang sejak awal perencanaan, tidak pada tahap pelaksanaannya saja.

\section{Kepemimpinan}

- Pemimpin mesti kuat seperti pohon beringin, sebagai tempat berlindung, panutan, tahan kritik, mau menerima saran, dan tidak menggurui

- Penghormatan diberikan kepada kualitas pemimpin, bukan pada kedudukannya; raja alim raja disembah, raja lalim raja disanggah.

- Kedudukan seorang pemimpin hanyalah didahulukan selangkah, ditinggikan seranting, karena itu, diingatkan agar hatihati yang di atas, yang di bawah akan menimpa.

- Menolak "kultus individu" dan pola "patron klien".

\section{Sikap kritis terhadap perubahan.}

Ide perubahan ditanggapi secara kritis, pro dan kontra. Hal itu lumrah dan bahkan niscaya terjadi. Konflik dalam masyarakat Minangkabau sebagaimana terefleksi dalam proses musyawarah, bukanlah gambaran kekakuan dan ketertutupan budaya, melainkan merupakan gambaran keterbukaan dan kelenturan mereka. Perbedaan pendapat dan perdebatan diperlukan untuk menemukan bentuk dan formula yang ideal.

5. Pola interaksi antar individu dalam proses sosial didasari prinsip egalitarian \& demokrasi

- Tidak ada yang memerintah dan yang diperintah (apalagi yang menguasai dan dikuasai). Yang dilaksanakan adalah keputusan bersama melalui proses musyawarah.
- Penghargaan kepada setiap orang adalah sama. Meskipun setiap orang berbeda peran dan kemampuannya, masing-masing setara dan sama fungsionalnya dalam kehidupan masyarakat.

- Pergeseran ke pola feodalistik dianggap sebagai kontaminasi kultural.

6. Tanah merupakan faktor yang sangat penting, secara ekonomis/praktis dan emosional/ sentimental.

- Tanah ulayat (tanah pusaka) merupakan identitas, dimiliki secara komunalmatrilineal-clan, dan bukan merupakan komoditi yang dapat diperjualbelikan.

- Pengalihan hak hanya dimungkinkan melalui wakaf dan hibah, di samping melalui cara yang sangat dihindarkan: pagang gadai.

- Kalaupun sekarang telah terjadi perubahan dan penyimpangan dari ketentuan dimaksud, dan merupakan sumber persengketaan yang umum dan banyak terjadi, namun ketentuan tersebut masih tetap dipertahankan.

Berikut ilustrasi penerapan karakter masyarakat Minangkabau dalam mendukung pelaksanaan program Agroforestry di Kabupaten Limapuluh Kota.

1. Dalam melakukan sosialisasi untuk memberikan pemahaman/pengetahuan tentang apa itu agroforestri kepada masyarakat maka sangat dibutuhkan pemilihan orang yang berpengaruh/disegani seperti : pemimpin adat/pemimpin agama/cendekiawan (otoritas). Dalam hal ini disarankan beberapa alternatif :

a. Melibatkan cendekiawan (praktisi/pakar) dari perguruan tinggi berlatar belakang dari bidang Agroforestry dan berasal dari Kabupaten Limapuluh Kota.

b. Jika tidak tersedia opsi a, maka pola sosialisasi menggunakan perpaduan antara pakar yang bukan berasal dari Kabupaten Limapuluh Kota dengan pemimpin adat/agama setempat. 
2. Terkait dengan prinsip musyawarah/mufakat dapat diterapkan pada saat perencanaan sampai tahap pelaksanaan yang akan melahirkan kesepakatan yang dilaksanakan secara bersama. Alvon Kurnia Palma, 2015 menyampaikan bahwa tahap perencanaan meliputi kapan akan dilakanakan, siapa yang akan melaksanakan, biaya dari mana dan berapa biaya yang akan dikeluarkan. Musyawarah/mufakat juga dapat berperan pada saat pelaksanaan untuk menentukan jenis tanaman, pola tanam (model agroforestri) dan pemeliharaan tanaman.

3. Terkait dengan sikap kritis terhadap perubahan

Program agroforestri merupakan suatu perubahan sistem tanam. Dengan adanya perubahan tersebut, otomatis masyarakat menunjukkan sikap pro dan kontra. Adanya perbedaan pendapat yang menciptakan konflik harus dianggap sebagai sesuatu yang wajar dan lumrah. Oleh sebab itu, untuk menghasilkan suatu keputusan akan menghabiskan waktu yang panjang/lama sehingga dibutuhkan kesabaran dan perencanaan yang matang.

4. Terkait dengan tanah

Penggunaan lahan untuk program agroforestri harus mendapat persetujuan dari pemilik lahan baik perorangan maupun ulayat/kaum.

\section{KESIMPULAN}

1. Agroforestri dapat dijadikan sebagai alternatif kebijakan untuk pemulihan lahan kritis di Kabupaten Limapuluh Kota dengan pertimbangan tanahnya peka erosi dan didominasi oleh kelerengan $>40 \%$.

2. Karakter budaya masyarakat Minangkabau yang unik dan khas harus dijadikan dasar/pertimbangan untuk mendukung program Agroforestri

\section{REKOMENDASI}

1) Pemerintah daerah melalui instansi terkait seyogyanya memasukkan kebijakan agroforestry dalam dokumen perencanaan dan didukung oleh anggaran yang memadai. 2).
Disarankan agar melakukan kajian/penelitian lanjutan terkait dengan : a.Pemetaan sosial ekonomi dan lingkungan untuk mengetahui kondisi sosial ekonomi dan lingkungan dalam mendukung program Agroforestri atau Pemilihan model agroforestri yang sesuai dengan kondisi sosial budaya dan serta ekologi setempat (vegetasi, tanah, iklim). b Pendataan yang akurat terkait dengan besaran dan lokasi lahan kritis terbaru di Kabupaten Limapuluh Kota.

\section{UCAPAN TERIMAKASIH}

Terima kasih kepada Allah Subhanahu Wata'ala yang telah memberikan kemudahan dan kelancaran dalam penyusunan Karya Tulis Ilmiah ini.

Terima kasih saya ucapkan kepada keluarga yang sudah memberi dorongan dan semangat dalam penyusunan Karya Tulis Ilmiah ini .

Terima kasih saya ucapkan kepada Bapak DR. Hasanuddin, Dekan Fakultas Ilmu Budaya, UNAND Minang serta rekan-rekan yang telah membantu dalam penyusunan Karya Tulis Ilmiah ini.

\section{DAFTAR PUSTAKA}

Bujang Rusdman 2017. Program Agroforestri di Kabupaten Limapuluh Kota. Disampaikan dalam acara Rapat di Balitbang Provinsi Sumatera Barat,19 April 2017 dengan tema Perubahan Fungsi Lahan di Kabupaten Limapuluh Kota

Pusat Pengendalian Pembangunan Ekoregion Sumatera. 2016. Rencana Aksi Pengendalian Pencemaran dan Kerusakan DAS Kampar.

Siti Nurbaya Abu Bakar, Kongres Sungai Indonesia (KSI) II $2016 \mathrm{di}$ Bendungan Selorejo, Kabupaten Malang, Jawa Timur, 23 September 2016

Kantor Lingkungan Hidup Kabupaten Limapuluh Kota. 2015. Status 
Lingkungan Hidup Daerah Limapuluh Kota.

Aris Tri Cahyo Purnomo. 2015. Partisipasi Masyarakat dalam Perencanaan Pembangunan Desa Wisata di Desa Limbasari, Kecamatan Bobotsari, Kabupaten Purbalingga. Skripsi Fakultas Ilmu Pendidikan Universitas Gajah Mada.

Nurul Ikhsan, ST. 2015. Perspektif Pengelolaan Lahan Kritis Berkelanjutan. Bappeda Kepulauan Bangka Belitung.

Helen Tiorita. 2012. Rehabilitasi Lahan Kritis dengan Sistem Agroforestry. Diakses tanggal 19 Agustus 2016.

Badan Pusat Statistik (BPS) Kabupaten Limapuluh Kota. 2015. Kabupaten Limapuluh Kota dalam Angka.

Hasanuddin. 2013. Adat dan Syarak, Sumber Inspirasi dan Rujukan Nilai
Dialektika Minangkabau. Pusat Studi dan Informasi Kebudayaan Minangkabau, Universitas Andalas, Padang.

Alfon Kurnia Palma. Lembaga. 2005. Kearifan Lokal Dalam Pengelolaan SDA (Kekayaan Nagari Menatap Masa Depan), Lembaga Bantuan Hukum (LBH) Padang.

Gerson ND. Njurumana dkk.2008. Potensi Pengembangan Mamar Sebagai Model Hutan Rakyat dalam di Rehabilitasi Hutan di Timor Barat. Balai Penelitian Kehutanan Kupang.

Kurniatun Hariah, dkk. 2003. Pengantar Agroforestri. World Agroforestry Center (ICRAF).

Saleh, Abdul Aziz. 1996. Pendekatan Sosio Kultural dalam Pembangunan di Sumatera Barat. Jurnal Genta Andalas. Volume 3, Tahun I. 